Teologia i Moralność, Volumen 13(2018), numer 1(23)

doi: 10.14746/tim.2018.23.1.3

\author{
JAROSŁAW KUPCZAK \\ Uniwersytet Papieski Jana Pawła II w Krakowie \\ Wydział Teologiczny
}

\title{
Walter Kasper i Joseph Ratzinger o komunii dla osób rozwiedzionych i w powtórnych związkach ${ }^{1}$
}

W niecałe pół roku po rozpoczęciu pontyfikatu papież Franciszek zwołał swój pierwszy Synod Biskupów. Biuro prasowe Stolicy Apostolskiej podało 8 października 2013 roku, że w dniach 5-19 października następnego roku w Watykanie odbędzie się nadzwyczajna sesja Synodu Biskupów poświęcona tematowi: „Wyzwania duszpasterskie związane z rodziną w kontekście ewangelizacji" (Comunicato 2013). Nadzwyczajne zgromadzenie Synodu Biskupów w 2014 roku zostało zaplanowane jako przygotowanie do kolejnej, zwyczajnej sesji Synodu Biskupów, która miała odbyć się rok później, w październiku 2015 roku.

Jesienią 2013 roku rozpoczęły się intensywne przygotowania do nadzwyczajnej sesji Synodu. Dziesięć dni po ogłoszeniu w Watykanie decyzji o zwołaniu synodu, 18 października 2013 roku nowy sekretarz generalny Synodu Biskupów, arcybiskup Lorenzo Baldisseri przesłał do przewodniczących wszystkich konferencji biskupów na świecie krótki synodalny dokument przygotowawczy: Lineamenta, w którym znajdujemy także kwestionariusz składający się z dziewięciu głównych pytań z wieloma pytaniami uzupełniającymi²

\footnotetext{
${ }^{1}$ Ten artykuł jest skróconą formą pierwszego rozdziału książki Źródla sporu o Amoris laetitia, Poznań 2018.

2 Pytania dotyczą, m.in. tego, w jakim stopniu, zdaniem respondentów, katolicy znają, rozumieją i akceptują nauczanie Kościoła w dyskutowanej sferze, czy idea prawa naturalnego w nauczaniu o małżeństwie spotyka się ze zrozumieniem, jak zatroszczyć się o wiarę dzieci w związkach nieregularnych, jak wygląda sytuacja osób w związkach homoseksualnych, czy nauka encykliki Humanae vitae Pawła VI jest odpowiednio przekazywana małżonkom i akceptowana przez nich itp. Lineamenta możemy odnaleźć w: https://pl.scribd.com/document/180575701/ Vatican-questionnaire-for-the-synod-on-the-family [dostęp: 31.05.2017].
} 
W liście, który towarzyszył ankiecie, arcybiskup Baldisseri thumaczył biskupom, że zgodnie z intencjami papieża kwestionariusz ma służyć przedsynodalnym konsultacjom; powinny one objąć jak największą liczbę wiernych i nie unikać podejmowania kontrowersyjnych tematów, takich jak: antykoncepcja i aborcja, brak akceptacji dla nauczania Kościoła, związki między osobami tej samej płci itp. Opracowane odpowiedzi powinny być przesłane do Watykanu do końca stycznia 2014 roku, tak aby sekretariat synodu mógł w lutym 2014 roku dokonać analizy zebranych z całego świata odpowiedzi i na ich podstawie napisać właściwy dokument przygotowawczy dla synodu: Instrumentum laboris.

W czasie, kiedy do Watykanu spływały z całego świata odpowiedzi na przedsynodalny kwestionariusz, 20-21 lutego 2014 roku w Rzymie odbył się konsystorz kardynałów, którego głównym zadaniem była wstępna dyskusja na temat dwóch synodów o rodzinie. O wygłoszenie wprowadzającego wykładu, który miał być punktem odniesienia dla debaty kardynałów, został poproszony przez papieża kardynał Walter Kasper. Przemówienie niemieckiego kardynała początkowo nie miało być publikowane; szybko jednak okazało się, że wzbudziło ono tak gorącą dyskusję i protest wielu uczestników konsystorza, iż przeniknięcie tego tekstu do prasy było tylko kwestią czasu. Całe przemówienie kardynała Kaspera ukazało się w mediolańskim dzienniku „Il Foglio” (Kasper 2014) 1 marca 2014 roku; wkrótce - najpierw w języku niemieckim, potem włoskim i angielskim - ukazała się książka kardynała Kaspera, Ewangelia rodziny, zawierająca jego przemówienie i uzupełniająca je aneksami oraz informacjami bibliograficznymi na temat cytowanych źródeł, szczególnie jeśli chodzi o ojców Kościoła ${ }^{3}$.

Z punktu widzenia późniejszych kontrowersji synodalnych i dyskusji nad adhortacją postsynodalną Amoris laetitia najistotniejszym fragmentem wystąpienia kardynała Kaspera jest jej piąta część zatytułowana: „Problem osób rozwiedzionych i znajdujących się w powtórnych związkach" (Il problema dei divorziati risposati). Zdaniem autora, sytuacja dzisiejszych rodzin, a szczególnie „gwałtownie wzrastająca liczba rozpadających się rodzin staje się coraz większą tragedią”, co wymaga od Kościoła ,zmiany paradygmatu (un cambiamento del paradigma)" (Kasper 2014, s. 41; także por. s. 8). Oznacza to nowe przemyślenie całości podejścia duszpasterskiego Kościoła do małżeństwa i ro-

${ }^{3}$ Najpierw ukazało się niemieckie wydanie tej książki: Walter Kardinal Kasper, Evangelium der Familie, Verlag Herder GmbH, Freiburg im Breisgau, 2014, które zawiera oryginalny tekst przemówienia kardynała w języku niemieckim. Ten tekst został przed publikacją zaprezentowany przez kardynała na auli synodalnej w języku włoskim, stąd włoskie wydanie traktujemy tutaj na równi z oryginałem niemieckim i to wydanie cytujemy w tym tekście: Il Vangelo della famiglia, Queriniana, Brescia 2014. Wydanie angielskie: The Gospel of the Family, Paulist Press, Mahwah, NJ, 2014. 
dziny na różnych stadiach ich rozwoju. Nie chodzi więc jedynie o wyseparowany z całości zagadnienia problem dopuszczania osób rozwiedzionych do komunii ani też jedynie o „rozważanie problemu wyłącznie z punktu widzenia i perspektywy Kościoła jako instytucji sakramentalnej (instituzione sacramentale)" (Kasper 2014, s. 41).

Kasper podkreśla, że w poszukiwaniu nowego paradygmatu duszpasterskiego i doktrynalnego Kościół „nie może proponować rozwiązania różnego od słów Jezusa czy przeciwnego do nich. Nierozerwalność małżeństwa sakramentalnego i niemożność zawarcia nowego małżeństwa podczas życia partnera jest częścią tradycji wiary wiążącej Kościół, która nie może być porzucona albo rozwodniona przez odniesienie do rozumianego powierzchownie taniego miłosierdzia" (Kasper 2014, s. 42)4. Jako pewien przykład i inspirację na drodze poszukiwania rozwiązania niemiecki kardynał odwołuje się do doświadczenia Soboru Watykańskiego II, kiedy wydawało się wielu ojcom Soboru, że nowe rozwiązania dotyczące ekumenizmu i wolności religijnej stoją w sprzeczności z dotychczasową nauką Kościoła. Mimo tych obaw Sobór był w stanie wypracować zadowalającą większość syntezę teologiczną w tych budzących wątpliwości dziedzinach, która poprawnie interpretuje tradycję wiary w nowych czasach.

Przechodząc do bardziej szczegółowych rozwiązań i propozycji teologicznych, kardynał Kasper koncentruje się w swoim przemówieniu na analizie trzech różnych problemów dotyczących małżeństwa: zagadnienia ważności sakramentu małżeństwa przyjmowanego przez ochrzczonych i niewierzących małżonków, pytania o możliwość uproszczenia kanonicznej procedury stwierdzania nieważności małżeństwa oraz postulacie udzielania komunii osobom rozwiedzionym, które znajdują się w ponownych związkach. W tym artykule, ze względu na ograniczenia miejsca, dokonamy prezentacji i analizy wypowiedzi kardynała Kaspera tylko jeśli chodzi o ostatni z tych tematów ${ }^{5}$.

Kardynał Kasper uważa, że dotychczasowa praktyka Kościoła, polegająca na tym, że osoby rozwiedzione, które znajdują się w ponownych związkach, zachęca się do komunii duchowej z Chrystusem, odmawiając im równocześnie możliwości przyjęcia komunii sakramentalnej, jest niewystarczająca (por. FC, nr 84; KKK 1650; Kongregacja Nauki Wiary 2015, s. 263-277). Jakie argumenty przemawiają za zmianą tej praktyki? Pierwszy dotyczy samego celu porządku sakramentalnego, którym jest pomoc duchowa dla wierzących, a szczególnie dla tych, którzy tego najbardziej potrzebują: ,jeśli odmawiamy sakramentów chrześcijanom rozwiedzionym w powtórnych związkach, którzy

${ }^{4}$ W swojej książce autor konsekwentnie używa określenia „partner”, także na określenie współmałżonka.

${ }^{5}$ Bardziej kompletna analiza ukaże się we wspomnianej książce: Źródła sporu o Amoris laetitia. 
są do nich odpowiednio dysponowani i odnosimy ich do pozasakramentalnej drogi zbawienia, czy nie kwestionujemy w ten sposób fundamentalnej struktury sakramentalnej Kościoła? A więc, czemu służy Kościół i jego sakramenty?" (Kasper 2014, s. 47). W tym kontekście Kasper stawia zarzut instytucjonalnej instrumentalizacji członków Kościoła: ,czy to nie jest instrumentalizacja osoby, która cierpi i szuka pomocy, jeśli czynimy ją znakiem i ostrzeżeniem dla innych? Zostawiamy ją, aby sakramentalnie umarła z głodu, aby inni żyli?" (Kasper 2014, s. 48).

Niewątpliwie, w tym oskarżeniu sformułowanym przez niemieckiego kardynała o niemiłosierne rozumienie sakramentów Kościoła odnajdujemy echo słów papieża Franciszka z adhortacji Evangelii gaudium. Mówiąc o „Kościele otwartych drzwi”, papież wzywał także do „otwarcia bramy sakramentów” i przypominał, że w Kościele, który jest „szpitalem polowym”, Eucharystia nie jest „nagrodą dla doskonałych, lecz szlachetnym lekarstwem i pokarmem dla słabych" (EG, nr 46-47).

Kardynał Kasper znajduje potwierdzenie swojego postulatu udzielania komunii osobom rozwiedzionym i znajdującym się w powtórnych związkach w praktyce starożytnego Kościoła. Podczas sporu doktrynalnego dotyczącego „upadłych” (lapsi), czyli chrześcijan, którzy podczas prześladowań zaparli się wiary, Kościół wypracował praktykę kanonicznej pokuty jako drugiego chrztu, już „nie wodą, ale łzami pokuty”. Jak pisze autor, odnosząc się do tekstów Soboru Trydenckiego o pokucie: „Po katastrofie grzechu, rozbitek nie powinien mieć do dyspozycji drugiego statku, ale stół zbawienia” (Kasper 2014, s. 48). Tak więc, w starożytności w niektórych Kościołach istniało prawo zwyczajowe, na mocy którego chrześcijanie znajdujący się w drugim związku, mimo że współmałżonek nadal był przy życiu, po okresie pokuty byli dopuszczani do przyjmowania komunii: otrzymywali nie „drugi statek”, ale dostęp do „stołu zbawienia”. Jak wskazuje Kasper, Orygenes, mówiąc o tej praktyce, określa ją jako niesprzeciwiającą się rozsądkowi (non irragionevole), odnoszą się do niej św. Bazyli i Grzegorz z Nazjanzu, także Augustyn „w jednym punkcie nie wyklucza wszelkich możliwych rozwiązań pastoralnych" (Kasper 2014, s. 49) 6 . U źródeł takiego zachowania ojców Kościoła było pragnienie ,uniknięcia tego, co gorsze" (evitare di peggio); dlatego ,tolerowali to, co w samym sobie jest niemożliwe do akceptacji" (Kasper 2014, s. 49). Mamy tutaj do czynienia z ,pastoralną praktyką tolerancji, łaski i odpustu”, która została potwierdzona na Soborze Nicejskim w sporze z rygoryzmem nowacjan.

Taka praktyka starożytnego Kościoła, kontynuuje Kasper, wskazuje nam dzisiaj via media między laksyzmem i rygoryzmem. $Z$ jednej strony przy-

\footnotetext{
${ }^{6}$ Dane bibliograficzne interesujących nas tutaj tekstów podamy nieco później podczas dyskusji nad artykułem Josepha Ratzingera.
} 
pominamy, że „miłosierdzie Boże nie było i nie jest tanią łaską (una grazia a buon mercato), która dyspensuje od nawrócenia" (Kasper 2014, s. 50). $\mathrm{Z}$ drugiej strony Kasper powołuje się na adhortację papieża Franciszka Evangelii gaudium, „sakramenty nie są nagrodą dla tych, którzy się dobrze zachowują, i dla elity, wykluczającą tych, którzy najbardziej ich potrzebują (EG 47). Miłosierdzie dotyczy wierności Boga w Jego miłości do grzeszników, którymi wszyscy jesteśmy i której także wszyscy potrzebujemy" (Kasper 2014, s. 50).

Po zarysowaniu doktrynalnego i pastoralnego tła swojego stanowiska kardynał Kasper przechodzi do wyraźnego przedstawienia pięciu warunków, których spełnienie mogłoby zaowocować w udzielaniu komunii osobom rozwiedzionym w ponownych związkach. Pierwszy warunek to żal z powodu rozpadu swojego pierwszego małżeństwa. Drugi warunek: wszystkie zobowiązania wynikające z pierwszego małżeństwa zostały spełnione, co sprawia, że ta osoba już nie będzie zwracała się wstecz (è definitivamente escluso che torni indietro). Trzeci warunek dotyczy tego, że nie można opuścić współmałżonka w drugim małżeństwie cywilnym bez zaciągnięcia nowych win; taka sytuacja miałaby miejsce w sytuacji, kiedy w drugim związku małżonkowie mają obowiązek troszczyć się wspólnie o dzieci zrodzone w tym związku. Czwarty warunek dotyczy wysiłku, aby według swoich najlepszych możliwości (al meglio delle sue possibilità) żyć w drugim małżeństwie wiarą oraz wychowywać swoje dzieci w wierze. Piąty warunek dotyczy istnienia u danej osoby pragnienia sakramentów jako źródła siły w nowej sytuacji. Zdaniem Kaspera, przy spełnieniu tych warunków i po upływie pewnego czasu takie osoby powinny otrzymać rozgrzeszenie i sakramentalną komunię.

Kardynał Kasper zastrzega, że zaproponowane powyżej rozwiązanie nie będzie nigdy „rozwiązaniem ogólnym” (una soluzione generale), „szeroką drogą dla wielu, ale raczej wąską ścieżką dla prawdopodobnie mniejszej części osób rozwiedzionych i żyjących w powtórnych związkach, poważnie zainteresowanej sakramentami” (Kasper 2014, s. 51). Takie rozwiązanie pozwoli uniknąć w przyszłości jeszcze jednego negatywnego scenariusza, które może dotknąć jedno pokolenie po drugim: „dzieci takich osób, nie widząc rodziców przyjmujących sakramentów, także nie odnajdą swojej drogi do spowiedzi i komunii" (Kasper 2014, s. 51).

Ze strony Kościoła otworzenie takiej drogi dla osób rozwiedzionych i żyjących w powtórnych związkach wymaga dwóch rzeczy. Po pierwsze, należy odróżnić małżeństwo cywilne od innych form nieregularnego współżycia, jak: „małżeństwa ukryte, związki pozamałżeńskie (le coppie di fatto), a przede wszystkim cudzołóstwo i sposoby współżycia more uxorio (konkubinat, wilde Ehe)". Jak podkreśla kardynał Kasper, ,życie nie jest tylko białe i czarne, ma wiele odcieni". Po drugie, proponowane rozwiązanie wymaga od Kościoła „umiejętności osądu” (discretio) i - kardynał używa tutaj kolejnego słowa - 
klucza w teologii papieża Franciszka - „duchowego rozeznawania” (discernimento sprituale).

Co ciekawe, kardynał Kasper w przedstawionej powyżej argumentacji na rzecz udzielania komunii osobom rozwiedzionym i żyjącym w powtórnych związkach odnosi się do artykułu Josepha Ratzingera z 1972 roku: Zur Frage nach der Unauflöslichkeit der Ehe. Bemerkungen zum dogmengeschichtlichen Befund und zu seiner gegenwärtigen Bedeutung (Ratzinger 1972, s. 35-56). Ponieważ ten tekst Ratzingera, wówczas profesora teologii na uniwersytecie w bawarskim Regensburgu, jest chyba najbardziej klarownym i przekonującym przedstawieniem argumentów na rzecz rozwiązania proponowanego przez Kaspera (ze szczególnym uwzględnieniem świadectw ojców Kościoła), warto go tutaj bardziej szczegółowo omówić. Sama ewolucja poglądów Ratzingera, którą opiszemy później, jest również ważnym argumentem w naszym sporze $^{7}$.

Joseph Ratzinger podkreśla na początku swojego artykułu, że każda próba dogmatycznej wypowiedzi na temat nierozerwalności małżeństwa może być dokonana tylko „Z uwzględnieniem całej konstrukcji kościelnej Tradycji: w staraniu o rozpoznanie jej najważniejszych czynników, wyjaśnienie jej napięć i tym samym w doprowadzeniu do rozróżnienia między Tradycją pierwszorzędną i drugorzędną, co może jednocześnie ustanowić kryteria dla dalszego rozwoju tej kwestii" (Ratzinger 2017, s. 539). Dlatego też struktura artykułu ma charakter chronologiczny: autor przedstawia opinie ojców Kościoła na ten temat, później analizuje średniowieczny rozwój teologii w tej dziedzinie, aby na koniec poddać refleksji współczesne problemy i pytania. $Z$ wielu wątków tego artykułu wybierzemy wyłącznie ten, który znalazł wierne odbicie (!) w analizowanym tutaj przemówieniu kardynała Waltera Kaspera.

Pierwsze zasadnicze podsumowanie swoich analiz świadectw patrystycznych Ratzinger formułuje w następujący sposób (zbieżny ze stanowiskiem Kaspera z Ewangelii rodziny): „Ojcowie na Wschodzie i Zachodzie są od początku zgodni co do całkowitej niemożliwości rozdzielenia chrześcijańskiego małżeństwa, który mógłby prowadzić do ponownego zawarcia związku małżeńskiego za życia małżonka; w obydwu częściach Kościoła nie da się znaleźć jakichkolwiek oznak przeciwnego poglądu. Świadectwo jest jasne" (Ratzinger

${ }^{7}$ Kiedy ten tekst Ratzingera został zacytowany przez kardynała Kaspera na konsystorzu w lutym 2014 roku, do druku był przygotowywany w języku niemieckim kolejny, czwarty tom Opera omnia Ratzingera, w którym miały znaleźć się wszystkie teksty dotyczące małżeństwa, w tym także Zur Frage nach der Unauflöslichkeit. Kiedy tom czwarty ukazał się jesienią 2014 roku, okazało się, że emerytowany papież Benedykt XVI zmienił uwagi końcowe swojego artykułu, co odzwierciedla także zmianę poglądów samego autora w podejściu do dyskutowanej kwestii. Porównaniem obu zakończeń, oryginalnego z 1972 roku i nowego z 2014 roku, zajmiemy się w dalszej części tego tekstu. Tekst z 2014 roku znalazł się też w czwartym tomie polskiej edycji Opera omnia, skąd go cytujemy. 
2017, s. 543). Druga teza Ratzingera uzupełnia to, co zostało przed chwilą powiedziane: „W sferze niezwiązanej z klasycznym nauczaniem, znajdującej się niejako poniżej wzorcowej wykładni Kościoła, istniała niewątpliwie w duszpasterstwie praktyka pewnej elastyczności, wprawdzie postrzegana jako nie do końca zgodna z rzeczywistą wiarą Kościoła, ale też niewykluczona całkowicie" (Ratzinger 2017, s. 543).

Pierwsze świadectwo na poparcie drugiej tezy dostarczone jest przez Orygenesa w jego komentarzu do Ewangelii według św. Mateusza:

Już również niektórzy przełożeni Kościoła pozwolili przeciwko temu, co jest napisane, że kobieta za życia męża może wyjść za mąż. Oni postępują przez to przeciwko słowu Pisma [....] (cytowane są 1 Kor 7,39 i Rz 7,3), jednak nie całkiem bezsensownie. Wolno mianowicie przyjąć, że to postępowanie w sprzeczności do tego, co od początku w prawie i co zapisane, przysługiwało im dla uniknięcia gorszych rzeczy (Orygenes 1998, 14, 23 [PG 13, 1245]).

Orygenes formułuje pewną zasadę pastoralną: zachowanie przełożonych Kościoła jest przeciw temu, co czytamy w Piśmie Świętym, ale „nie jest całkiem bez sensu”, ponieważ pozwala ,uniknąć gorszych rzeczy”.

Ratzinger zwraca uwagę, że dwóch autorów z IV wieku proponuje konkretną formę „uniknięcia tego, co gorsze”. Na Zachodzie Ambrozjaster proponuje swoistą interpretację 1 Kor 7,11: żona nie powinna odchodzić od swojego męża, ale jeśli przypadek nierządu męża skłoni ją do tego (Ambrozjaster odnosi się tutaj do klauzuli nierządu z Mt 5,32), powinna pojednać się z mężem lub pozostać niezamężna. Podobnie mężczyzna nie powinien opuszczać swojej żony, ale jeśli skłoni go do tego przypadek nierządu żony (klauzula nierządu), może ożenić się ponownie, ponieważ Paweł w 1 Kor 7,11 nie traktuje równo mężczyzny i kobiety (por. PL 17, 218 B). Mimo raczej skromnej i nieprzekonującej argumentacji ten tekst Ambrozjastra cieszył się bardzo dużym poważaniem w średniowieczu, ponieważ przypisywano go św. Ambrożemu.

Inaczej temat „uniknięcia tego, co gorsze” podejmuje znany tekst z listu św. Bazylego, do którego odnosi się także Kasper w swoim przemówieniu (Ep 217, 77, PG 32, 804n; thum. polskie: Bazyli Wielki, Listy, thum. W. Krzyżaniak, Warszawa 1972, s. 77). Od chrześcijan żyjących w drugim związku Bazyli oczekuje siedmiu lat pokuty kościelnej - rok na stopniu płaczących, dwa lata jako słuchający, trzy lata jako klęczący, w siódmym roku mogą oni, nie przystępując do Komunii, uczestniczyć we $\mathrm{Mszy}^{8}$. Dopiero po tym czasie surowej pokuty chrześcijanie żyjący w drugim związku dopuszczeni są do Komunii Świętej. Ratzinger zwraca uwagę, że - podobnie jak Orygenes - Bazyli

${ }^{8}$ Nawet bez thumaczenia szczegółów tych praktyk pokutnych, możemy zrozumieć, jak były surowe. 
zdaje sobie sprawę z tego, że taka praktyka jest sprzeczna z Pismem Świętym, ale dla dobra wierzących nie chce z niej zrezygnować.

Powyższe uwagi pokazują, że średniowieczna próba ujednolicenia i systematycznego wykładu teologii $\mathrm{w}$ dziedzinie małżeństwa była poważnym wyzwaniem. W XII wieku, Gracjan ma, po jednej stronie, jednoznaczną naukę i autorytet św. Augustyna z jego obroną nierozerwalności małżeństwa; z drugiej strony znajdują się powyżej cytowane świadectwa ojców, praktyka niektórych synodów prowincjalnych oraz zapisy występujące w księgach penitencjarnych. Wśród różnych świadectw bardziej tolerancyjnej praktyki kościelnej w odniesieniu do chrześcijan żyjących w powtórnych związkach Ratzinger odnosi się do dwóch. Pierwszym śladem takiej praktyki jest list papieża Grzegorza II do św. Bonifacego z 726 roku, gdzie papież naucza, że tam, gdzie kobieta z obiektywnych powodów, na przykład choroby, nie jest w stanie wypełniać powinności małżeńskich, mąż powinien żyć w czystości. Niemniej jednak, naucza papież: ,ponieważ ta kwestia jest moralnym heroizmem, ten, kto nie może się powstrzymać, lepiej powinien się ponownie ożenić" (Gracjan, D P 2 C 32 q 7 c 18; por. Regesta, 2174, cyt. w: Ratzinger 2017, s. 545). Drugim świadectwem bardziej tolerancyjnej praktyki kościelnej w odniesieniu do chrześcijan żyjących w powtórnych związkach jest zapis Concilium Triburiense synodu biskupów niemieckich z 895 roku. Z zapisów tego synodu Gracjan cytuje w swoich Dekretach ustalenie, że jeśli ktoś obcował ze swoją teściową, żadnej z obydwu stron nie wolno ponownie wchodzić w związek małżeński, ,ale jej mąż może, jeśli chce, wziąć inną kobietę, jeśli nie może się on powstrzymać" 9 .

Charakterystyczny jest sposób interpretacji dwóch powyższych świadectw przez Gracjana, który chce pozostać wierny nauce św. Augustyna o nierozerwalności małżeństwa. Jeśli chodzi o list Grzegorza II, kanonista z Bolonii mówi z zastanawiającą ostrością, że słowa papieża „stoją w sprzeczności ze świętymi kanonami, nauką ewangeliczną i apostolską" ${ }^{10}$. Jeśli chodzi o przypisywany św. Ambrożemu tekst Ambrozjastra, Gracjan wykazuje niesłychaną intuicję - chce osłabić jego znaczenie, twierdząc, że być może jest sfałszowany, a jego interpretacja nie jest pewna. Ratzinger zauważa, że najciekawsze są uwagi Gracjana na temat Concilium Triburiense. Boloński prawnik przedstawia zapis synodu jako „ustępstwo” (pro tempore permissum), które jest misyjną regułą przejściową, udzieloną czasowo „w sytuacji stopniowej przemiany od pogaństwa do chrześcijaństwa" (Ratzinger 2017, s. 547).

\footnotetext{
${ }^{9}$ Ta sama zasada obowiązuje w przypadku obcowania z innymi członkami rodziny: pasierbicą lub szwagierką.

${ }^{10}$ Gratian, D do c 18: Illud Gregorii sacris canonibus, immo evangelicae et apostolicae doctrinae penitus invenitur adversum.
} 
Podsumowując swoje rozważania na temat średniowiecznej interpretacji interesującego nas tutaj tematu, Ratzinger zauważa, że nauka i praktyka Kościoła szła w dwóch kierunkach. Z jednej strony chodziło o wierność bezkompromisowej nauce św. Augustyna o nierozerwalności małżeństwa; z drugiej strony chodziło o kompromis duszpasterski. W tym świetle teolog z Regensburga widzi głęboką jedność między Kościołami Wschodu i Zachodu, skoro również na Wschodzie tylko pierwsze małżeństwo jest małżeństwem sakramentalnym, każde następne jest związkiem jedynie tolerowanym z powodu miłosierdzia wobec grzeszników (oikonomia). Można postawić pytanie o to, ,jak to się stało, że na Zachodzie praktyka tolerującego przyzwolenia zniknęła w mgnieniu oka poniżej pełnej formy dogmatycznej wypowiedzi, na Wschodzie natomiast rozrosła się tak mocno, że prawie przysłoniła pełną formę" (Ratzinger 2017, s. 548). Zdaniem Ratzingera, kluczowa różnica polegała na tym, że na Wschodzie, gdzie istnieje Cesarstwo, „chrześcijańskie państwo tworzy chrześcijańskie prawo" (Ratzinger 2017, s. 548), które musi przybrać odpowiednio elastyczną formę, aby było akceptowalne przez władzę państwową. Na Zachodzie, gdzie brak jest we wczesnym średniowieczu władzy cesarskiej, jej plenipotencje przejmuje papież, a rozwój prawa następuje „wewnątrz kościelnej Tradycji z jej bardzo rygorystycznymi zobowiązaniami" (Ratzinger 2017, s. 548). Jak podsumowuje Ratzinger, „w jednym przypadku cesarskie, w drugim zaś papieskie prawo zdecydowanie kształtowało drogę rozwoju" (Ratzinger 2017, s. 548-549).

Trzecia część omawianego artykułu poświęcona jest Soborowi Trydenckiemu, w którym Kościół wypowiedział się wobec wyzwania reformacji. Jak wiemy, Marcin Luter interpretował słowa Pana o niemoralności oddalenia żony, ale „poza wypadkiem nierządu” (Mt 5,32), jako przyzwolenie na rozwód i powtórne małżeństwo ${ }^{11}$. Poza tym, małżeństwo było dla niego „rzeczą światową" (weltlich Ding), która nie powinna być poddana władzy kościelnej (papieskiej), ale świeckiej (państwowej). W odpowiedzi na tezy Lutra Sobór Trydencki tworzy siedem kanonów o teologii małżeństwa, w których broni nauki o sakramentalności i nierozerwalności małżeństwa.

Ratzinger zwraca jednak uwagę na pewną „duszpasterską niekonsekwencję” Kościoła w epoce Soboru Trydenckiego. W tym czasie w weneckich koloniach w basenie Morza Śródziemnego istniała osobliwa forma unii kościelnej z prawosławnymi, którzy uznawali władzę papieża, ale zachowywali wszystkie prawosławne tradycje włącznie z własną praktyką rozwodu. Jak powtarza Ratzinger za jezuickim historykiem Pietem Fransenem, ta różnica w praktyce i doktrynie widziana była wówczas jako różnica ,rytu”, z którą mamy do czynienia w jednym Kościele (por. Fransen 1954). Sobór Trydencki, odrzucając

${ }^{11}$ Dodatkowym argumentem dla ojca reformacji były słowa św. Pawła o tym, że „lepiej jest żyć w małżeństwie, niż płonąć" (1 Kor 7,9). 
tezy Lutra, nie potępił tej prawosławnej praktyki rozwodowej ze względu na jedność Kościoła, która wymaga - Ratzinger sięga tutaj do formuły św. Augustyna użytej w walce o jedność w rozdartym przez donatyzm Kościele w Afryce - tolerare pro pace (por. Ratzinger 2017, s. 553).

Pozostały nam do omówienia wnioski końcowe artykułu Josepha Ratzingera, a raczej dwie wersje wniosków końcowych. Jak już wspomnieliśmy, kiedy kardynał Kasper nawiązał do artykułu Ratzingera w swoim przemówieniu na konsystorzu w lutym 2014 roku, emerytowany papież Benedykt XVI przygotowywał do druku czwarty tom swoich Opera omnia w języku niemieckim, a w nim tekst, którym tutaj się zajmujemy. Kiedy czwarty tom ukazał się drukiem jesienią tego roku, okazało się, że artykuł z 1972 roku ma zmienione zakończenie. Ta zmiana nie jest przypadkowa; raczej, odpowiada ona zmianie poglądów autora tekstu. Dlatego też najpierw omówimy najważniejsze tezy oryginalnego, a potem nowego zakończenia w kontekście ewolucji poglądów Ratzingera $^{12}$.

Po uwagach o charakterze historycznym Ratzinger w zakończeniu swojego tekstu z 1972 roku przechodzi do konkretnych propozycji pastoralnych; zadziwiająca jest ich zbieżność z tymi, które zaprezentował kardynał Kasper na konsystorzu w lutym 2014 roku. Podstawą praktyki pastoralnej Kościoła musi być świadomość, że wymagania Ewangelii są głoszone w świecie, gdzie istnieje rzeczywistość ,zatwardziałego serca”. Dlatego też, kiedy powstaje taka potrzeba (in klaren Notsituationen), Kościół może zezwolić na ograniczone wyjątki (begrenzte Ausnahmen), aby uniknąć tego, co gorsze (Ratzinger używa tutaj określenia Orygenesa). Podstawowym kryterium i granicą stosowania takiego wyjątku, czyli działania ,przeciw temu, co jest napisane” (,gegen das, was geschrieben steht"), jest to, że takie działanie nie kwestionuje samej fundamentalnej formy (die Grundform), przez którą żyje Kościół. Taki wyjątek pozostaje czasowym rozwiązaniem, jak Ratzinger zauważył powyżej, na terenach misyjnych bądź w sytuacjach, gdzie zagrożona jest jedność Kościoła.

Następnie, profesor z Regensburga proponuje konkretne zastosowanie tego wyjątku w sytuacji Kościoła lat 70. ubiegłego wieku:

Jeśli pierwsze małżeństwo od jakiegoś czasu jest w stanie rozpadu w sposób nienaprawialny dla obu stron, a drugie małżeństwo po dłuższym czasie okazuje się stabilną i moralną rzeczywistością [eine sittliche Realität] oraz żyje duchem wiary, szczegól-

12 Obie wersje zakończenia dyskutowanego artykułu można znaleźć w „Herder Korrespondenz”, 68 (2014) 12, 609-612, https://www.herder-korrespondenz.de/heftarchiv/68-jahrgang-2014/heft122014/die-beiden-textversionen-von-joseph-ratzinger-benedikt-xvi-zur-frage-nach-der-un aufloeslichkeit-der-ehe [dostęp: 22.02.2017]. Stąd też cytujemy zakończenie tekstu z 1972 roku; zakończenie tekstu z 2014 roku - tak jak jego pozostałe fragmenty - cytujemy z polskiego wydania Opera omnia. 
nie w wychowaniu dzieci (tak że zniszczenie tego małżeństwa spowodowałoby szkody moralne), na drodze poza-jurydycznej [auf einem außergerichtlichen Weg], na podstawie świadectwa proboszcza i członków wspólnoty, takie osoby żyjące w drugim małżeństwie powinny otrzymać pozwolenie na przyjęcie komunii (Ratzinger 2014).

Zdaniem 45-letniego Ratzingera, istnieją dwa powody akceptacji takiej praktyki w Kościele. Po pierwsze, należy pamiętać, że w każdym procesie unieważnienia małżeństwa istnieje pewna uznaniowość (ein Ermessensspielraum) i nierówność szans, która jest związana $\mathrm{z}$ różnym poziomem edukacji zaangażowanych osób czy ich zamożnością. Dlatego też nie należy sądzić, że w takim orzecznictwie rzeczywiście zawsze „sprawiedliwości staje się zadość”. Ponieważ w procesie sądowym należy ograniczyć się do faktów prawnych, wiele spraw może nie być uwzględnionych bądź też kryteria formalne (np. błąd formy) mogą być w sposób nieuprawniony decydujące. Po drugie, pozwolenie na przyjęcie komunii przez osobę żyjącą w drugim związku, po zachowaniu warunków wyłożonych powyżej, odpowiada temu rodzajowi wyrozumiałości (die Nachsicht), o której mówił Bazyli w tekstach cytowanych wcześniej.

Ratzinger bardzo mocno podkreśla, że taka eucharystyczna praktyka Kościoła nie może oznaczać w żadnej mierze zmiany doktryny Kościoła w dziedzinie nierozerwalności małżeństwa. Raczej należy ją rozumieć w takim sensie, że „Eucharystyczna komunia Kościoła powinna także objąć osoby, które uznają tę doktrynę i tę zasadę życia, ale znajdują siebie w specjalnej sytuacji potrzeby (eine Notsituation besonderer Art), w której mają szczególną potrzebę pełnej komunii z Ciałem Chrystusa" (Ratzinger 2014).

Nową wersję uwag końcowych dyskutowanego artykułu Benedykt XVI napisał 42 lata później. Warto zwrócić uwagę na kilka ważnych wydarzeń w tym okresie. Po pierwsze, Międzynarodowa Komisja Teologiczna, której członkiem Joseph Ratzinger był od momentu jej powstania w 1969 roku, tworzy w 1977 roku dokument Doktryna katolicka o sakramencie malżeństwa; tworzący komisję teologowie, między nimi profesor Ratzinger, wypowiadają się w nim także na temat możliwości udzielania komunii osobom rozwiedzionym żyjącym w drugich związkach. Jeśli chodzi o nierozerwalność małżeństwa, dokument dokonuje bardzo ciekawej obserwacji rozwoju nauki Kościoła w tym względzie.

W odniesieniu do nauki Soboru Trydenckiego dokument Komisji potwierdza tezę Ratzingera z dyskutowanego tutaj artykułu o kompromisowym stanowisku Soboru:

Sobór Trydencki stwierdził, że Kościół nie znajduje się w błędzie, gdy nauczał i naucza, zgodnie z doktryną ewangeliczną i apostolską, że związek małżeński nie może zostać rozwiązany z powodu cudzołóstwa (DS 1807). Jednak Sobór obłożył anatemą 
jedynie tych, którzy odrzucali władzę Kościoła w tym względzie. Racji tej wstrzemięźliwości należy szukać w wątpliwościach, jakie pojawiły się w ciągu wieków (opinie Ambrozjastera, Katarinusa, Kajetana) oraz - z innego punktu widzenia - ze względu na perspektywy ekumeniczne. Nie można zatem twierdzić, że Sobór miał intencję uroczystego zdefiniowania nierozerwalności małżeństwa jako prawdy wiary (Doktryna katolicka 2000, s. 99).

Równocześnie jednak Komisja wskazuje na encyklikę Piusa XI Casti connubii z 1930 roku, w której znajdujemy - w komentarzu do orzeczeń Soboru Trydenckiego - znacznie bardziej zdecydowane twierdzenie o nierozerwalności małżeństwa: „Nie mylił się Kościół i nie myli się tak nauczając. Jest zatem rzeczą zupełnie pewną, że węzeł małżeński, nawet z powodu cudzołóstwa, rozerwanym być nie może. $Z$ tego wynika niewątpliwie, że wszelkie inne powody, słabsze jeszcze, zwykle na korzyść rozwodów przytaczane, mniej jeszcze mają wagi i pominięte być mogą" (CC, II 3, b). W kontekście zagadnienia nierozerwalności małżeństwa Komisja w następnym, piątym punkcie dokumentu podejmuje temat „Rozwiedzionych, który zawarli nowe związki”.

Nauka dokumentu Komisji w interesującej nas tutaj kwestii jest bardzo jasna. Zarówno ze słów Chrystusa (Mk 10,6n), jak też z nauczania św. Pawła, wynika jasno, że „nowe związki, zawarte po rozwodzie uzyskanym dzięki prawu cywilnemu, nie są ani prawidłowe, ani prawowite" oraz - w związku z tym - że

rozdźwięk między stanem rozwiedzionych, którzy zawarli nowe związki, a przykazaniem i tajemnicą miłości paschalnej Pana, stanowi dla tych osób przeszkodę do przyjęcia, w świętej Eucharystii, znaku zjednoczenia z Chrystusem. Dopuszczenie do Komunii eucharystycznej może nastąpić tylko po spowiedzi, która zakłada „żal za popełniony grzech i mocne postanowienie nie popełniania go więcej w przyszłości” (Sobór Trydencki, DS 1676) (Doktryna katolicka 2000, s. 101).

Obiektywny stan rozwiedzionych znajdujących się w nowych związkach sprawia, że nie mogą oni przyjąć znaku zjednoczenia z Chrystusem, którym jest komunia eucharystyczna - chyba że odwrócą się oni od grzechu.

Razem ze stworzonym przez siebie dokumentem Doktryna katolicka o sakramencie małżeństwa Międzynarodowa Komisja Teologiczna zaakceptowała na drodze głosowania jako własny tekst Szesnaście tez chrystologicznych o sakramencie małżeństwa Gustave’a Marteleta SJ. W tezie 12. „Rozwód i Eucharystia" czytamy:

Nie pomijając pewnych okoliczności łagodzących, a niekiedy także wartości małżeństwa cywilnego zawartego po rozwodzie, dostęp rozwiedzionych, którzy zawarli nowy związek, do Eucharystii pozostaje niezgodny z tajemnicą, której Kościół jest 
sługą i świadkiem. Dopuszczając takie osoby do Eucharystii, Kościół pozwalałby im wierzyć, że mogą one, na poziomie znaków, pozostawać w komunii z Tym, którego tajemnicę małżeńską odrzucają na poziomie rzeczywistości.

Uczynienie czegoś takiego oznaczałoby ponadto, że Kościół deklaruje zgodność z ochrzczonymi, w chwili gdy wchodzą oni bądź też pozostają w obiektywnej i oczywistej sprzeczności z życiem, myślą i samą naturą Pana jako Oblubieńca Kościoła. Jeśli Kościół udzielałby sakramentu jedności tym, którzy w istotnym punkcie tajemnicy Chrystusa odłączyli się od Niego, nie byłby on już znakiem i świadkiem Chrystusa, lecz anty-znakiem i anty-świadkiem (Doktryna katolicka 2000, s. 108-109).

Warto zauważyć istotną różnicę w rozumieniu komunii eucharystycznej, która występuje w omawianych tutaj tekstach Waltera Kaspera i Gustave'a Marteleta. Kasper mówi o komunii - w sposób bardzo zbliżony do papieża Franciszka - jako pomocy i lekarstwie dla słabych ludzi, używa metafory Kościoła jako „szpitala polowego”. Martelet - w sposób zbliżony do papieża Jana Pawła II i Benedykta XVI - zwraca uwagę na teologiczne i obiektywne znaczenie przyjmowania Eucharystii przez wiernych; przyjmowanie komunii jest znakiem, że życie komunikującego chrześcijanina jest w zasadniczych rysach zgodne z nauczaniem Kościoła. Ten argument Marteleta będzie powtarzany w kolejnych orzeczeniach Kościoła odmawiających komunii eucharystycznej osobom rozwiedzionym i znajdującym się w powtórnych związkach.

Omówiony powyżej dokument Międzynarodowej Komisji Teologicznej pochodzi z 1977 roku, kiedy profesor Joseph Ratzinger został mianowany przez Pawła VI arcybiskupem Monachium. W listopadzie 1981 roku monachijski kardynał otrzymał z rąk Jana Pawła II nominację na prefekta Kongregacji Nauki Wiary i tym samym stał się przewodniczącym Międzynarodowej Komisji Teologicznej, której dotąd był stałym członkiem. W 1981 roku Jan Paweł II publikuje, w czwartym roku swojego pontyfikatu, adhortację Familiaris consortio, która jest owocem jego przemyśleń po synodzie biskupów na temat „Zadań rodziny chrześcijańskiej w świecie współczesnym” z jesieni 1980 roku. W swojej adhortacji Jan Paweł II bardzo jednoznacznie stwierdza:

Kościół jednak na nowo potwierdza swoją praktykę, opartą na Piśmie Świętym, niedopuszczania do komunii eucharystycznej rozwiedzionych, którzy zawarli ponowny związek małżeński. Nie mogą być dopuszczeni do komunii świętej od chwili, gdy ich stan i sposób życia obiektywnie zaprzeczają tej więzi miłości między Chrystusem i Kościołem, którą wyraża i urzeczywistnia Eucharystia. Jest poza tym inny szczególny motyw duszpasterski: dopuszczenie ich do Eucharystii wprowadzałoby wiernych w błąd lub powodowałoby zamęt co do nauki Kościoła o nierozerwalności małżeństwa. Pojednanie w sakramencie pokuty - które otworzyłoby drogę do komunii eucharystycznej - może być dostępne jedynie dla tych, którzy żałując, że naruszyli znak 
Przymierza i wierności Chrystusowi, są szczerze gotowi na taką formę życia, która nie stoi w sprzeczności z nierozerwalnością małżeństwa. Oznacza to konkretnie, że gdy mężczyzna i kobieta, którzy dla ważnych powodów - jak na przykład wychowanie dzieci - nie mogąc uczynić zadość obowiązkowi rozstania się, postanawiają żyć w pełnej wstrzemięźliwości, czyli powstrzymywać się od aktów, które przysługują jedynie małżonkom (FC, $\mathrm{nr} 84$ ).

Dwanaście lat po opublikowaniu Familiaris consortio dokonał się następny akt w obserwowanym przez nas historycznym dramacie. Walter Kasper, wówczas biskup Stuttgartu, razem z dwoma innymi niemieckimi biskupami napisał list do papieża, w którym argumentuje na rzecz komunii dla osób rozwiedzionych, podkreślając, że nauczanie Familiaris consortio jest jedynie „ogólną i prawdziwą normą, która jednakże nie może regulować wszystkich bardzo skomplikowanych indywidualnych przypadków" (Bunderson 2014). Warto zauważyć, że ten argument powrócił w przemówieniu kardynała Kaspera na konsystorzu; wielokrotnie też powracał w debatach i dokumentach dwóch Synodów Biskupów o rodzinie z lat 2014-2015. Odpowiedzią na list biskupa Kaspera z 1992 roku jest publikowany przez Kongregację Nauki Wiary we wrześniu 1994 roku List do biskupów Kościoła katolickiego na temat przyjmowania Komunii św. przez wiernych rozwiedzionych żyjacych $w$ nowych zwiazkach, pod którym podpisany jest prefekt Kongregacji kardynał Joseph Ratzinger.

List Kongregacji rozpoczyna się od przedstawienia błędnych propozycji dotyczących przyjmowania Komunii Świętej przez wiernych rozwiedzionych żyjących w nowych związkach; w gruncie rzeczy możemy w tym opisie odrzuconych opinii rozpoznać nieomal cytaty z artykułu Ratzingera z 1972 roku:

Odnośnie do tego zagadnienia zostały zaproponowane w ubiegłych latach w różnych regionach rozwiązania duszpasterskie, zgodnie z którymi z pewnością nie jest możliwe powszechne dopuszczenie wiernych żyjących w nowych związkach do Komunii św., lecz mogliby oni być dopuszczeni do niej w określonych przypadkach, a mianowicie wtedy, kiedy według osądu ich sumienia czuliby się do tego upoważnieni. Tak, na przykład, gdyby zostali opuszczeni bez powodu, mimo że starali się i szczerze pragnęli uratować poprzednie małżeństwo lub gdyby byli przekonani w sumieniu o nieważności poprzedniego małżeństwa, nie mogąc jednak tego udowodnić na forum zewnętrznym, bądź też gdyby mieli już za sobą długą drogę refleksji i pokuty lub $\mathrm{z}$ istotnych względów moralnych nie mogliby spełnić obowiązku separacji. Zostało również zaproponowane przez niektórych, aby dla dokonania obiektywnej oceny rzeczywistej sytuacji żyjący w nowych związkach odbyli rozmowę z roztropnym i kompetentnym kapłanem. Kapłan ten musiałby uszanować ich ewentualną decyzję o przystąpieniu do sakramentu Eucharystii, co jednak nie byłoby równoznaczne z udzieleniem oficjalnego zezwolenia (Kongregacja Nauki Wiary 2015, nr 3). 
Odnosząc się do wcześniej omawianych fragmentów artykułu Ratzingera z 1972 roku, można powiedzieć, że w tym tekście prefekt Kongregacji krytykuje własne poglądy sprzed 22 lat.

Co ciekawe, list Kongregacji odnosi się także do świadectw ojców Kościoła, którzy aprobowali dyskutowaną praktykę:

Chociaż wiadomo, że analogiczne rozwiązania duszpasterskie były proponowane przez niektórych Ojców Kościoła i w pewnej mierze były stosowane w praktyce, to nie zostały one nigdy zaaprobowane przez Ojców i w żaden sposób nie stanowiły powszechnej nauki Kościoła, ani nie znalazły się w jego dyscyplinie. Obowiązkiem powszechnego Magisterium Kościoła, w imię wierności Pismu Świętemu i Tradycji, jest nauczanie oraz autentyczne interpretowanie depozytu wiary (Kongregacja Nauki Wiary 2015, nr 4).

Wobec pewnego absolutyzowania w dzisiejszej teologii danych patrystycznych kosztem dalszego rozwoju teologii i późniejszego Magisterium Kościoła to stwierdzenie Kongregacji Nauki Wiary, że pojedyncze świadectwa ojców „nigdy nie zostały zaaprobowane przez Ojców i w żaden sposób nie stanowiły powszechnej nauki Kościoła”, wydaje się ważną wskazówką hermeneutyczną w badaniu autentycznego nauczania Kościoła.

Po tych uwagach wstępnych dochodzimy do głównej tezy Listu:

wierny, który żyje stale na sposób małżeński (more uxorio) z osobą, która nie jest prawowitą małżonką albo prawowitym mężem, nie może przystępować do Komunii św. Jeśli zaś sądzi on, że jest to możliwe, ze względu na ciężkość materii i na to, czego wymaga dobro duchowe osoby oraz dobro wspólne Kościoła, pasterze i spowiednicy muszą pouczyć go, że taki sąd sumienia jawnie sprzeciwia się nauczaniu Kościoła (Kongregacja Nauki Wiary 2015, nr 6).

Kongregacja przypomina także, że ze względu na obiektywny charakter małżeństwa decyzji co do tego, czy poprzednie małżeństwo było ważne czy nie, nie można jedynie pozostawiać subiektywnemu osądowi (sumieniu) mężczyzny czy kobiety, ale należy ją powierzyć obiektywnemu osądowi Kościoła ${ }^{13}$.

Wspomniane powyżej wypowiedzi Kościoła, które ukazały się w latach 1977-2007 i przy których powstawaniu co najmniej współpracował Joseph Ratzinger, tworzą ważne tło do zrozumienia nowego zakończenia artykułu Ratzingera z roku 1972, które napisał już jako emerytowany papież w 2014 roku. Autor rozpoczyna od refleksji nad nierozerwalnością małżeństwa, na którą patrzy od strony teologicznej (,«Tak» małżeństwa ma udział w Kościele

13 Benedykt XVI potwierdził tę naukę w posynodalnej adhortacji Sacramentum caritatis z lutego 2007 roku (por. SC, nr 29). 
w owej ostateczności, która stała się widoczna w ostatecznej decyzji Boga wobec człowieka”) i antropologicznej („Małżeństwo należy do fundamentalnych decyzji ludzkiej egzystencji, które tylko całkowicie albo wcale nie mogą być podjęte, właśnie ponieważ w niej sam człowiek uczestniczy jako cały, aż do owej głębi, w której jest przez Chrystusa dotknięty”). Równocześnie, tak rozumiana radykalność małżeństwa jest zakwestionowana we współczesnej kulturze, w której, z jednej strony, redukcja człowieka do przeżycia i świadomości sprawia, że jeśli uczucie między małżonkami wygasa, kończy się więź (ne$x u s)$; z drugiej strony, „wyprzedaż człowieka na rzecz «Chronosu», zmieniających się bożków danej chwili i swoistej chwilowości" sprawia, że człowiek nie chce podejmować decyzji, które sięgają daleko w przyszłość (Ratzinger 2017, s. 553-554).

W tej często niesprzyjającej wierze postnowoczesności Kościół musi pozostać wierny słowom Chrystusa o nierozerwalności małżeństwa, ale równocześnie z powodów duszpasterskiej troski „musi wybadać granice i rozpiętość słów Chrystusa". Benedykt XVI zauważa, że w historii teologii małżeństwa można wskazać na dwa precedensy takiego teologicznego i duszpasterskiego „badania”. Śladem pierwszego są słowa św. Pawła z 1 Kor 7,12-16, gdzie apostoł mówi, że małżeństwo między chrześcijaninem i niechrześcijaninem może być rozwiązane, jeśli niechrześcijanin przeszkadza chrześcijaninowi w wierze. Opierając się na słowach św. Pawła, tradycja Kościoła

wyprowadziła myśl, że tylko małżeństwo między dwojgiem ochrzczonych jest rzeczywistym sakramentem i dlatego jest absolutnie nierozerwalne. Małżeństwa między niechrześcijaninem a chrześcijaninem są wprawdzie małżeństwami w porządku stworzenia i przez to w sobie ostateczne. Mogą one jednak być rozwiedzione na korzyść wiary i małżeństwa sakramentalnego (Ratzinger 2017, s. 555).

Obok przywileju Pawłowego tradycja Kościoła wprowadziła ideę przywileju Piotrowego, w którym tylko papież może rozwiązać małżeństwo, w którym przynajmniej jedna ze stron jest ochrzczona, a małżeństwo nie zostało skonsumowane (non consumatum).

Drugim historycznym śladem badania ,granic i rozpiętości słów Chrystusa" dotyczących nierozerwalności małżeństwa jest nauka Kościoła o przeszkodach małżeńskich oraz o nieważności zawartego małżeństwa. Jak stwierdza Kościół, małżeństwo konstytuuje się poprzez wzajemną zgodność woli mężczyzny i kobiety, która musi być wyrażona także publicznie w jednej zdefiniowanej przez prawo formie (por. KPK 1057 § 1). Jak zauważa Benedykt XVI, „,prawo kościelne zakłada przy tym, że dorośli ludzie sami z siebie, ze swej natury wiedzą, czym jest małżeństwo i tak też wiedzą o jego ostateczności; przeciwieństwo tego musiałoby być wyraźnie udowodnione” (Ratzinger 2017, 
s. 556; por. KPK $1096 \S 1$ i $\S 2$ ). Zdaniem emerytowanego papieża, to założenie prawa kościelnego otwiera drogę do licznych pytań i wątpliwości:

Czy dzisiaj można jeszcze zakładać, że ludzie „z natury” wiedzą o ostateczności i nierozerwalności małżeństwa i potwierdzają to swoim „tak”? Czy we współczesnym społeczeństwie, w każdym razie w krajach zachodnich, nie dokonała się zmiana świadomości, która każe się liczyć z opinią przeciwną? Czy można zakładać jako oczywistą wolę do ostateczności, lub czy raczej nie oczekiwać przeciwieństwa, że już z góry jest się nastawionym na niepowodzenie? Czy tam, gdzie ostateczność byłaby świadomie wykluczona, małżeństwo w sensie woli Stwórcy i jej interpretacji przez Chrystusa nie zostałoby rzeczywiście zawarte? (Ratzinger 2017, s. 556-557).

Ta nieoczywistość przekonania nupturientów o nierozerwalności małżeństwa stwarza nowe pytania przede wszystkim w kontekście orzekania o nieważności małżeństwa. Szerszy kontekst tego problemu otwiera kanon 1095, 3, gdzie czytamy, że niezdolne do zawarcia małżeństwa są osoby, które „z przyczyn natury psychicznej nie są zdolne podjąć istotnych obowiązków małżeńskich" (KPK 1096 § 3). Niewątpliwie, nierzadko dzisiejsza kultura powoduje u młodych ludzi różne formy takiej niedojrzałości.

Najbardziej radykalnym sposobem postawienia takiego pytania o ważność małżeństwa jest sytuacja „ochrzczonych pogan” zawierających małżeństwo. W swoim tekście z 2014 roku Benedykt XVI nie podaje gotowych odpowiedzi, raczej zadaje pytania i zachęca do dalszej refleksji:

Kan. 1055 § 2 mówi, że „między ochrzczonymi nie może istnieć ważna umowa małżeńska, która tym samym nie byłaby sakramentem". Ale jak to jest, jeśli niewierzący ochrzczony w ogóle nie zna sakramentu? Może on mieć wolę do nierozerwalności, jedynie nie dostrzega on nowości wiary chrześcijańskiej. Dramat tej sytuacji staje się widoczny przede wszystkim, kiedy pogańscy ochrzczeni nawracają się do wiary i zaczynają zupełnie nowe życie (Ratzinger 2017, s. 557-558).

Benedykt XVI kończy swój tekst trzema praktycznymi propozycjami. Po pierwsze, chodzi o większe zaangażowanie osób rozwiedzionych i znajdujących się w nowych związkach w życie Kościoła. Emerytowany papież sugeruje, że „należałoby przyznać im możliwość stania się aktywnymi w kościelnych gremiach oraz przejąć również zadanie chrzestnych, co jak dotąd nie jest przewidziane przez prawo" (Ratzinger 2017, s. 558). Po drugie, należy poddać krytycznej weryfikacji praktykę, w której większość bądź całość wspólnoty obecnej na Eucharystii przystępuje do komunii, co sprawia, że niemożność przystąpienia do komunii osób rozwiedzionych i znajdujących się w nowych związkach jest dla nich szczególnie „raniąca”. Autor sugeruje, że z większą powagą należałoby potraktować ostrzeżenie św. Pawła: „Niech przeto człowiek 
baczy na siebie samego, spożywając ten chleb i pijąc z tego kielicha. Kto bowiem spożywa i pije nie zważając na Ciało [Pańskie], wyrok sobie spożywa i pije" (1 Kor 11,28n). Decyzja o nieprzystępowaniu czasami do komunii byłaby również formą solidarności z osobami rozwiedzionymi i znajdującymi się w nowych związkach, które do komunii nie powinny przystępować. Trzecia praktyczna wskazówka Benedykta XVI dotyczy wprowadzenia zwyczaju, że osoby, które nie mogą przyjmować komunii, przychodziłyby do ołtarza razem z tymi, którzy komunię przyjmują, aby otrzymać błogosławieństwo od kapłana.

\section{Uwagi końcowe}

Podjęta $\mathrm{w}$ tym tekście próba omówienia niektórych wątków z przemówienia kardynała Waltera Kaspera na konsystorzu kardynałów w lutym 2014 roku przerodziła się w porównanie dwóch teologii: Waltera Kaspera i Josepha Ratzingera. To porównanie prowokuje do szeregu refleksji końcowych, które mają bardzo różny charakter. Pierwsza refleksja dotyczy oceny zaprezentowanej zmiany w poglądach Josepha Ratzingera. Ta zmiana poglądów wiązała się ze zmianą pozycji Ratzingera: artykuł z 1972 roku był napisany przez wykładowcę teologii na uniwersytecie w Ratyzbonie; zmiana poglądów wiązała się w czasie z nominacją na biskupa Monachium, a potem z funkcją prefekta Kongregacji Nauki Wiary i wreszcie - następcy św. Piotra. Dla niektórych komentatorów zmiana teologicznych poglądów Ratzingera była więc po prostu rezygnacją z osobistych poszukiwań teologicznych w celu głoszenia ex officio tradycyjnej nauki Kościoła. Zdaniem autora tego tekstu, taka opinia nie uwzględnia tego, że pasterska troska o Kościół nie sprzeciwia się właściwie rozumianej niezależności myślenia. Wprost przeciwnie, miłość do Kościoła i pasterska odpowiedzialność za wspólnotę wierzących w tradycji Kościoła były zawsze znakiem prawdziwej i wielkiej teologii. Dlatego też zmiana poglądów Ratzingera powinna być widziana jako wyraz dojrzewania jego wizji w dyskutowanych tutaj kwestiach, a nie oportunizmu czy rezygnacji z niezależności myślenia. Przeciwna opinia jest głęboko krzywdząca dla Josepha Ratzingera, którego przecież nawet jego krytycy w przeszłości nazywali Panzerkardinal ze względu na odwagę i bezkompromisowość w głoszeniu prawdy.

Druga refleksja końcowa dotyczy faktu, że kardynał Kasper doskonale wiedział o ewolucji poglądów Josepha Ratzingera. Zastanawia więc czytelnika fakt, że odnosi się on w swoim tekście do wczesnej wypowiedzi Ratzingera, a w żaden sposób nie podejmuje polemiki z późniejszymi, poważnymi wypowiedziami Kongregacji Nauki Wiary, Międzynarodowej Komisji Teologicznej, a przede wszystkim dwóch kolejnych papieży, które tworzą najnowsze Magisterium Kościoła w odniesieniu do dyskutowanych kwestii: Jana Paw- 
ła II i Benedykta XVI. Niepodejmowanie przez kardynała Kaspera dyskusji z jego krytykami i ignorowanie przeciwnych opinii jest zresztą powracającym zarzutem wobec niego.

Jednym z najpoważniejszych głosów krytycznych wobec analizowanego tutaj przemówienia kardynała Kaspera jest książka Pozostać w prawdzie Chrystusa, której redaktorem jest dawny rektor rzymskiego Instytutu Patrystycznego Augustinianum, Robert Dodaro. Wśród autorów artykułów w tej zbiorowej pozycji jest pięciu kardynałów, jeden arcybiskup i trzech teologów; każdy z nich z różnej perspektywy dokonuje krytyki tez zawartych w przemówieniu kardynała Kaspera ${ }^{14}$. Jeden z najciekawszych tekstów w tym zbiorze został napisany przez Johna Rista, wybitnego znawcę starożytności, który poddaje krytyce najmocniejsze z argumentów użytych przez kardynała Kaspera: dotyczących praktyki starożytnego Kościoła. Nie mamy tutaj możliwości dokładnego streszczenia argumentacji kanadyjskiego patrologa; zacytujmy jedynie wnioski końcowe:

chociaż wśród starożytnych chrześcijan powtórne małżeństwa za życia współmałżonka były zazwyczaj zabronione, a tym, którzy je zawarli, odmawiano Komunii Świętej, istniała niewielka, ale zauważalna liczba wyjątków od tej reguły, lecz niemal zawsze spotykały się z potępieniem. Chociaż nie znamy przyczyn tych wyjątków i możemy tylko spekulować na ten temat, z pewnością wiemy, że są wyjątkami i tak właśnie musimy je traktować, ponieważ chrześcijanie w starożytności postrzegali jakiekolwiek bardziej „miłosierne” podejście do rozwiedzionych, którzy zawarli ponowne małżeństwo, za proste zaprzeczenie nakazom samego Chrystusa. W takim razie, jakie by nie były dobre czy złe strony zmian w obecnej praktyce Kościoła rzymskokatolickiego, jest oczywiste, że takich zmian nie można poprzeć znaczącymi świadectwami ze świata pierwszych wieków chrześcijaństwa. Jeśli pytamy, jak to możliwe, że są tacy, którzy przywołują starożytne świadectwa jako część argumentacji na rzecz zmian, możemy jedynie dojść do wniosku, że są oni (lub źródła, na których się opierają) winni nieszczęsnej praktyki aż nazbyt rozpowszechnionej w innych obszarach działalności naukowej; ale istnieje bardzo niewiele przypadków - przy czym być może nawet one są w przeważającej mierze niejednoznaczne w swej wymowie - które wskazują na przeciwny wniosek. Wtedy twierdzi się, że chociaż świadectwa nie opowiadają się za zmianami, to przynajmniej nie przesądzają o rozwiązaniu, pozostawiając kwestię otwartą. Takie postępowanie zasługuje wyłącznie na potępienie jako metodologicznie błędne (Rist 2015, s. 90-91).

${ }^{14}$ Włoska, oryginalna wersja książki ukazała się w październiku 2014 roku, w ostatnim tygodniu trwania nadzwyczajnej sesji Synodu o Rodzinie: Permanere nella verità di Cristo. Matrimonio e comunione nella Chiesa cattolica, a cura di R. Dodaro, Cantagalli, Siena, 2014. Tutaj cytujemy z polskiego thumaczenia: Pozostać w prawdzie Chrystusa. Matżeństwo i komunia w Kościele katolickim, red. R. Dodaro, thum. K. Markiewicz, A. Sikora, M. Wiertlewska, Poznań 2015. 
Niezależnie od merytorycznych błędów w argumentacji kardynała Waltera Kaspera, warto raz jeszcze na koniec zwrócić uwagę na kluczowy element w XX-wiecznej nauce Magisterium Kościoła o niedopuszczaniu osób rozwiedzionych i znajdujących się w powtórnych związkach do Komunii Świętej. Ten kluczowy element nie dotyczy tego, czy są one subiektywnie w stanie łaski uświęcającej, czy nie; ostatecznie to wie tylko Bóg. Raczej, wskazane powyżej dokumenty Magisterium Kościoła zwracają uwagę na teologiczne i obiektywne znaczenie przyjmowania Eucharystii przez wiernych; przyjmowanie komunii jest znakiem, że życie komunikującego chrześcijanina jest w zasadniczych rysach zgodne z nauczaniem Kościoła. Ten argument jest powtarzany w kolejnych orzeczeniach Kościoła odmawiających komunii eucharystycznej osobom rozwiedzionym i znajdującym się w powtórnych związkach.

\section{WALTER KASPER AND JOSEPH RATZINGER ON COMMUNION FOR THE DIVORCED AND IN SECOND MARRIAGES}

\section{SUMMARY}

The subject of the article is a critical presentation of Cardinal Walter Kasper's speech delivered at the Cardinal Consistory in February 2014, with the aim of preparing the Synod of Bishops on "The Pastoral Challenges of the Family in the Context of the Evangelization". From several of Kasper's important themes, which have influenced decisively the synodal discussion, this article chooses his postulate of changing the practice of the Church in the field of access to Eucharistic communion for the divorced and remarried people. Kasper's argument was confronted with Joseph Ratzinger's views in this field, with particular emphasis on their evolution in 1972-2005.

Słowa kluczowe: komunia święta; małżeństwo; miłosierdzie; nierozerwalność małżeństwa; osoby rozwiedzione i znajdujące się w powtórnych związkach; sakrament małżeństwa

Keywords: holy communion; marriage, mercy; indissolubility of marriage; persons divorced and remarried; sacrament of marriage

\section{BIBLIOGRAFIA} niak, Warszawa. 
Benedykt XVI (2007), Posynodalna adhortacja apostolska Sacramentum caritatis, http://w2.vatican. $\mathrm{va} /$ content/benedict-xvi/pl/apost_exhortations/documents/hf_ben-xvi_exh_20070222_sacra mentum-caritatis.html [dostęp: 02.09.2017].

Bunderson C. (2014), Scholars: No, Benedict XVI doesn't support Kasper in synod debates, Catholic News Agency, 25.11.2014; http://www.catholicnewsagency.com/news/scholars-no-benedictxvi-doesnt-support-kasper-in-synod-debates-35882 [dostęp: 11.09.2017].

Comunicato della Sala Stampa della Santa Sede: III Assemblea Generale Straordinaria del Sinodo dei Vescovi (5-19 ottobre 2014), "Bolletino Sala Stampa", 08.10.2013 (http://press.vatican.va/ content/salastampa/it/bollettino/pubblico/2013/10/08/0640/01436.html [dostęp: 02.09.2017].

Doktryna katolicka o sakramencie malżeństwa (2000), w: Od wiary do teologii. Dokumenty Międzynarodowej Komisji Teologicznej 1969-1996, red. J. Królikowski, Kraków.

Ehescheidung. Diskussion unter Christen (1972), hg. von F. Henrich, V. Eid, Münchener Akademie-Schriften 59, München, s. 35-56.

Franciszek (2013), Adhortacja apostolska Evangelii gaudium, http://w2.vatican.va/content/francesco/pl/apost_exhortations/documents/papa-francesco_esortazione-ap_20131124_evangelii-gaudium.html [dostęp: 11.09.2017].

Fransen P. (1954), Ehescheidung bei Ehebruch Die theologischen und geschichtlichen Hintergründe der ersten Stellungnahme zum 7. Kanon in der 24. Sitzung des Trienter Konzils (Juli 1563), Freiburg.

Gracjan. Decretum, Pars 2, Causa 32, q. 7 c. 18; PL 187, 1501-1502.

Jan Paweł II (1981), Adhortacja apostolska Familiaris consortio, https://opoka.org.pl/biblioteka/W/ WP/jan_pawel_ii/adhortacje/familiaris.html [dostęp: 11.09.2017].

Kasper W. (2014), Bibbia, eros e famiglia, „Il Foglio Quotidiano” 1 marzo 2014; http://www.intams. org/website/intams/assets/files/bestanden_PDF/kasper.pdf; [dostęp: 02.09.2017].

Kasper W. (2014), Evangelium der Familie, Freiburg im Breisgau.

Kodeks prawa kanonicznego (2014), red. A. Flisek, W. Żelazowska, Warszawa.

Kongregacja Nauki Wiary (2015), List do biskupów Kościoła katolickiego na temat przyjmowania Komunii św. przez wiernych rozwiedzionych żyjacych w nowych zwiąkach, w: Pozostać w prawdzie Chrystusa. Matżeństwo i komunia w Kościele katolickim, red. R. Dodaro, thum. K. Markiewicz, A. Sikora, M. Wiertlewska, Poznań, s. 263-277.

Międzynarodowa Komisja Teologiczna (2000), Doktryna katolicka o sakramencie matżeństwa, w: Od wiary do teologii. Dokumenty Międzynarodowej Komisji Teologicznej 1969-1996, red. J. Królikowski, Kraków, s. 89-110.

Orygenes (1998), Commentarius in Mathaei Evangelium 14, 23; PG 13, 1245; thum. polskie: Orygenes, Komentarz do Ewangelii według Mateusza, tłum. K. Augustyniak, Źródła Myśli Teologicznej, 10, Kraków, s. 226-227.

Pius XI (1930), Casti connubii, http:/18/www.opoka.org.pl/biblioteka/W/WP/pius_xi/encykliki/ casti_connubi_31121930.html [dostęp: 13.09.2017].

Pozostać w prawdzie Chrystusa. Matżeństwo i komunia w Kościele katolickim (2015), red. R. Dodaro, thum. K. Markiewicz, A. Sikora, M. Wiertlewska, Poznań.

Ratzinger J. (2017), Kwestia nierozerwalności małżeństwa. Uwagi do orzeczenia dogmatyczno-historycznego i jego wspótczesnego znaczenia, w: J. Ratzinger, Wprowadzenie do chrześcijaństwa. Wyznanie - chrzest - naśladowanie, tłum. R. Biel, M. Górecka, Opera Omnia, t. IV, red. K. Góźdź, M. Górecka, Lublin, s. 539-559.

Ratzinger J. (1972), Zur Frage nach der Unauflöslichkeit der Ehe. Bemerkungen zum dogmengeschichtlichen Befund und zu seiner gegenwärtigen Bedeutung, in: Ehe und Ehescheidung. Diskussion unter Christen, hg. von F. Henrich, V. Eid., Münchener Akademie-Schriften 59, München, s. 35-56.

Ratzinger J., Zur Frage nach der Unauflöslichkeit der Ehe. Bemerkungen zum dogmengeschichtlichen Befund und zu seiner gegenwärtigen Bedeutung, in: Ehe und Synodus Episcoporum, Lineamenta, https://pl.scribd.com/document/180575701/Vatican-questionnaire-for-the-synodon-the-family, [dostęp: 31.05.2017]. 
Ratzinger J. (1972), Zur Frage nach der Unauflöslichkeit der Ehe. Bemerkungen zum dogmengeschichtlichen Befund und zu seiner gegenwärtigen Bedeutung „Herder Korrespondenz”, 68, 12, 609-612, https:/www.herder-korrespondenz.de/heftarchiv/68-jahrgang-2014/heft-122014/diebeiden-textversionen-von-joseph-ratzinger-benedikt-xvi-zur-frage-nach-der-unaufloeslichkeitder-ehe [dostęp: 22.02.2017].

Rist J.M. (2015), Rozwód i matżeństwo we wczesnym Kościele: kilka refleksji historycznych i kulturowych, w: Pozostać w prawdzie Chrystusa malżeństwo i komunia w Kościele katolickim, red. R. Dodaro, tłum. K. Markiewicz, A. Sikora, M. Wiertlewska, Poznań 2015, s. 90-91.

JAROSŁaw KuPCZAK OP - prof. dr hab., ur. 1964, kierownik Katedry Antropologii Teologicznej na Wydziale Teologicznym oraz dyrektor Ośrodka Badań nad Myślą Jana Pawła II Uniwersytetu Papieskiego Jana Pawła II w Krakowie. Wykłada także w: Kolegium Filozoficzno-Teologicznym oo. Dominikanów w Krakowie oraz Pontificio Istituto Giovanni Paolo II per studi su Matrimonio e Famiglia w Rzymie. Ostatnio opublikowane książki: Teologiczna semantyka ptci, WAM, Kraków 2013; Gift and Communion. John Paul II's Theology of the Body, The Catholic University of America Press, Washington, D.C. 2014; Karol Wojtyla Jan Pawet II o czlowieku, Wydawnictwo Naukowe Uniwersytetu Papieskiego Jana Pawła II, Kraków, 2018; Źródta sporu o Amoris laetitia, W drodze, Poznań 2018. 